\title{
Casein fraction of ovine milk from indigenous Greek breeds
}

\author{
Golfo MOATSOU ${ }^{\mathrm{a} *}$, Maria SAMOLADA ${ }^{\mathrm{b}}$, Alexandra KATSABEKI ${ }^{\mathrm{a}}$, \\ Emmanuel ANIFANTAKIS ${ }^{\mathrm{a}}$ \\ a Laboratory of Dairy Technology, Department of Food Science and Technology, \\ Agricultural University of Athens, Iera Odos 75, 11855 Athens, Greece \\ b Laboratory of Dairy Technology, Department of Agricultural Science, \\ Aristotle University of Thessaloniki, 54006 Thessaloniki, Greece
}

Received 22 July 2003 - Accepted 21 November 2003

Published online 26 March 2004

\begin{abstract}
Whole casein fractions isoelectrically prepared from bulk milks from four different indigenous Greek ovine breeds were analysed by urea-PAGE and reversed-phase HPLC. Individual caseins prepared by fractionation on a cation-exchange column were used to locate the peaks on the chromatograms. Apart from heterogeneity that was depicted in the peak shape of caseins, there was also quantitative variability regarding the $\alpha_{\mathrm{s}}$ - and $\beta$-casein contents. According to the RP-HPLC results, the relative percentages of individual caseins ranged as follows: $\kappa$-casein from $9.1 \%$ to $10.8 \%, \alpha_{\mathrm{s} 2}$-casein from $12.0 \%$ to $16.4 \%, \alpha_{\mathrm{s} 1}$-casein from $33.9 \%$ to $39.9 \%$ and $\beta$-casein from $37.0 \%$ to $42.3 \%$. According to the results obtained by both methods, the composition of the casein fraction from the Karagouniko breed was the most different, since it had the greatest $\beta$-casein content and the lowest $\alpha_{\mathrm{s}}$-casein to $\beta$-casein ratio. The relative percentages of the individual caseins in two of the four breeds (Frisarta and Chios) were similar. The quantification results of urea-PAGE and RPHPLC analyses were in general similar with respect to the means. However, the relative standard deviations of the chromatographic method were better and this was also true for the resolution of the components of the whole casein fraction.
\end{abstract}

\section{Ovine casein / indigenous ovine breeds / chromatography / RP-HPLC / electrophoresis}

Résumé - Fractions caséiques des laits de mélange provenant de troupeaux de brebis indigènes grecques. Les fractions caséiques des laits de mélange de quatre troupeaux de brebis indigènes grecques ont été analysées par électrophorèse en gel de polyacrylamide à $\mathrm{pH}$ alcalin en présence d'urée (urée-PAGE) et par chromatographie liquide haute performance en phase inversée (RPHPLC). L'identification des caséines a été effectuée par l'analyse des caséines individuelles préparées par chromatographie d'échange de cations. Les résultats des analyses par RP-HPLC ont démontré que le contenu en caséines principales variait dans les proportions suivantes: caséine $\kappa$, de 9,1 à $10,8 \%$, caséine $\alpha_{\mathrm{s} 2}$, de 12,0 à $16,4 \%$, caséine $\alpha_{\mathrm{s} 1}$, de 33,9 à $39,9 \%$ et caséine $\beta$, de 37,0 à $42,3 \%$. Les résultats obtenus par les deux méthodes ont démontré que la fraction caséique du troupeau Karagouniko était la plus différente parmi les laits analysés ; elle a présent la plus haute teneur en caséine $\beta$ et le plus faible rapport caséine $\alpha_{\mathrm{s} 1}$ sur caséine $\beta$. Les pourcentages relatifs des caséines individuelles de deux des quatre troupeaux étudiés étaient en général similaires. La résolution et les écarts types relatifs estimés par la chromatographie, étaient meilleurs que ceux estimés par uréePAGE.

\section{Caséine de brebis / troupeaux de brebis indigènes / chromatographie / électrophorèse}

\footnotetext{
* Corresponding author: mg@aua.gr
} 


\section{INTRODUCTION}

The composition of ovine milk, which is rich in proteins and fat, results in excellent cheesemaking properties. A great variety of ovine cheeses with particular characteristics are produced in the Mediterranean area. Caseins are responsible for the enzymatic coagulation of milk and their hydrolysis pattern is a very important characteristic of cheese ripening.

Although bovine and more recently caprine caseins have been extensively characterised by a variety of analytical methods, the publications about ovine casein are more limited. They are for the most part studies on the characterisation and the polymorphism of individual caseins $[1,2,7-11,15-17,34,36,37]$. Limited information exists regarding the relative percentages of the individual caseins in the whole casein fraction of ovine milks [8, 21, 27, 33]. The influence of the $\alpha_{\mathrm{s} 1}$-casein genotype and therefore of the composition of the casein fraction on the micelle structure and the cheesemaking properties of caprine milk has been studied quite extensively [28-30, 35, 39]. The influence of genetic polymorphism of the proteins on the technological properties of ovine milk has been reviewed by Amigo et al. [3]. Regarding the influence of the casein genotype, it has been reported that the $\alpha_{s 1}$-casein genotype affects milk production [12], total protein and casein content, the casein micelle diameter and the composition of the whole casein fraction [31-33]. Consequently, it affects the cheesemaking properties of ovine milk with respect to renneting performance and cheese yield [12, 23, 32, 33].

The purpose of the present work was to study the casein fractions of four Greek indigenous ovine herds by estimating the relative amounts of the individual caseins in the whole casein fraction. For this purpose electrophoretic and chromatographic methods were used.

\section{MATERIALS AND METHODS}

\subsection{Preparation of whole casein}

Bulk milks from four flocks that corresponded to different Greek indigenous ovine breeds named Karagouniko, Boutsiko, Chios and Frisarta were collected. After centrifugation at $2000 \times g$ for $30 \mathrm{~min}$ at $4{ }^{\circ} \mathrm{C}$, the skim milks were acidified at $\mathrm{pH} 4.5$ with acetic acid $\left(1 \mathrm{~mol} \cdot \mathrm{L}^{-1}\right)$ under continuous stirring at $25^{\circ} \mathrm{C}$. After settling for $20 \mathrm{~min}$, the mixture was filtered through Whatman No. 40 paper. The precipitated casein was washed with distilled water, dissolved with the addition of $\mathrm{NaOH} 10 \mathrm{~g} \cdot \mathrm{L}^{-1}$ until it reached $\mathrm{pH} 7.0$ and precipitated again. Four successive cycles of precipitation and washing were carried out. The final precipitate was dissolved in $20 \mathrm{mmol} \cdot \mathrm{L}^{-1}$ phosphate buffer, $\mathrm{pH} 7.0$, heated at $80{ }^{\circ} \mathrm{C}$ for $30 \mathrm{~min}$ to inactivate plasmin, dialysed (MWCO $12 \mathrm{~kg} \cdot \mathrm{mol}^{-1}$, Sigma-Aldrich Chemie Gmbh, Steinheim, Germany) against distilled water and lyophilised. The same procedure was followed for the preparation of whole bovine casein from a Holstein-Friesian flock.

\subsection{Casein hydrolysis by chymosin}

Whole casein was treated with fermentation-produced chymosin (Maxiren ${ }^{\circledR} 150$, Gist-Brocades, Delft, The Netherlands) according to McSweeney et al. [24]. Solutions of ovine whole casein $\left(30 \mathrm{mg} \cdot \mathrm{mL}^{-1}\right)$ in $0.1 \mathrm{~mol} \cdot \mathrm{L}^{-1}$ phosphate buffer, $\mathrm{pH} 6.6$, containing sodium azide $\left(5 \mathrm{mg} \cdot 100 \mathrm{~mL}^{-1}\right)$ were heated to $30^{\circ} \mathrm{C}$. The clotting activity of chymosin solutions in $0.1 \mathrm{~mol} \cdot \mathrm{L}^{-1}$ phosphate buffer, $\mathrm{pH}$ 6.6, was determined in $10 \mathrm{~mL}$ ovine skim milk supplemented with $10 \mathrm{mmol} \cdot \mathrm{L}^{-1} \mathrm{CaCl}_{2}$ at $30^{\circ} \mathrm{C}$. One unit of the enzyme was determined as the amount of enzyme required to coagulate $10 \mathrm{~mL}$ of milk in $100 \mathrm{~s}$ at $30^{\circ} \mathrm{C}$. The casein solutions were incubated with chymosin solution in a ratio of 0.5 enzyme units per $\mathrm{mL}$ of casein solution at $30^{\circ} \mathrm{C}$ for 20 and $180 \mathrm{~min}$. At the end of each incubation time, the chymosin 
was inactivated by heating at $65^{\circ} \mathrm{C}$ for $30 \mathrm{~min}$. Hydrolysates were dissolved in urea-polyacrylamide gel electrophoresis (urea-PAGE) sample buffer in a ratio 1:4 and they were analysed by alkaline ureaPAGE.

\subsection{Casein hydrolysis by plasmin}

The treatment of whole casein with bovine plasmin (E.C. 3.4.21.7, Boehringer, Mannheim, Germany) was carried out according to the Commission Regulation [13]. Ovine casein $\left(10 \mathrm{mg} \cdot \mathrm{mL}^{-1}\right)$ was dissolved in $0.2 \mathrm{~mol} \cdot \mathrm{L}^{-1}$ ammonium hydrogen carbonate buffer, $\mathrm{pH} 8.0$, and $5 \mu \mathrm{L}$ bovine plasmin were added. After incubation at $40{ }^{\circ} \mathrm{C}$ for $60 \mathrm{~min}$, aminocaproic acid was added to inactivate the enzyme. Hydrolysates were dissolved in urea-PAGE sample buffer in a ratio 1:4 and they were analysed by alkaline urea-PAGE.

\subsection{Urea-PAGE of casein}

Whole caseins and their hydrolysates were analysed by the urea-PAGE method of Andrews [4] with direct staining using Coomassie Brilliant Blue G-250 [6]. Electrophoresis was carried out on a vertical slab unit (LKB 2001, Amersham Pharmacia Biotech, Uppsala, Sweden) in slabs $140 \times$ $160 \times 1.5 \mathrm{~mm}$. Separation gels of $\mathrm{T}=$ $12.5 \%$ and $\mathrm{C}=4 \%$ were used. Ten $\mu \mathrm{L}$ of whole casein solutions $\left(2 \mathrm{mg} \cdot \mathrm{mL}^{-1}\right)$ were put in stacking gel buffer containing $8 \mathrm{~mol} \cdot \mathrm{L}^{-1}$ urea and $0.1 \mathrm{~mol} \cdot \mathrm{L}^{-1} \beta$-mercaptoethanol. Then after incubation at $40{ }^{\circ} \mathrm{C}$ for $20 \mathrm{~min}$, they were analysed. The gels were run under constant current of $60 \mathrm{~mA}$ at $10{ }^{\circ} \mathrm{C}$ and the duration of the analysis was about $2.5 \mathrm{~h}$. After destaining with water, the gel slabs were scanned using a scanner (Hewlett Packard, ScanJet 4c/T, USA) and the protein bands were quantified by an image processing system (GelCompar v. 4.0, Applied Maths, Kortrijk, Belgium). Duplicates of each sample were analysed in each gel and four independent electrophoretic runs were carried out for each sample.

\subsection{Cation-exchange (CE) chroma- tography of whole caseins}

Lyophilised whole caseins were fractionated by cation-exchange chromatography on a SP-Sepharose Hiload 26/10 column (Amersham Pharmacia Biotech) using a Waters 650E automated chromatographic system with a tunable absorbance detector (Waters Model 486, Waters, Milford, MA, USA). A modification of the method of Hollar et al. [19] was applied. Buffer A was $20 \mathrm{mmol} \cdot \mathrm{L}^{-1} \mathrm{Na}$ acetate $6 \mathrm{~mol} \cdot \mathrm{L}^{-1}$ urea, $\mathrm{pH}$ 5.0, and buffer B was similar to A but also contained $1 \mathrm{~mol} \cdot \mathrm{L}^{-1} \mathrm{NaCl}$. Sixty $\mathrm{mL}$ of lyophilised casein solution $\left(7 \mathrm{mg} \cdot \mathrm{mL}^{-1}\right)$ prepared according to Hollar et al. [19] were applied onto the column. Firstly the sample was applied onto the column at a flow rate of $2 \mathrm{~mL} \cdot \mathrm{min}^{-1}$ and it was washed with buffer $\mathrm{A}$ at a flow rate of $3 \mathrm{~mL} \cdot \mathrm{min}^{-1}$ for $15 \mathrm{~min}$. Then a $\mathrm{NaCl}$ gradient was formed by mixing buffer $\mathrm{A}$ with buffer $\mathrm{B}$ at a flow rate of $3 \mathrm{~mL} \cdot \mathrm{min}^{-1}$, as follows: from 0 to $0.08 \mathrm{~mol} \cdot \mathrm{L}^{-1} \mathrm{NaCl}$ within $15 \mathrm{~min}$, from 0.08 to $0.10 \mathrm{~mol} \cdot \mathrm{L}^{-1}$ within $45 \mathrm{~min}$, from 0.10 to $0.12 \mathrm{~mol} \cdot \mathrm{L}^{-1}$ within $15 \mathrm{~min}$, from 0.12 to $0.14 \mathrm{~mol} \cdot \mathrm{L}^{-1}$ within $50 \mathrm{~min}$, from 0.14 to $0.20 \mathrm{~mol} \cdot \mathrm{L}^{-1}$ within $20 \mathrm{~min}$ and from 0.20 to $0.30 \mathrm{~mol} \cdot \mathrm{L}^{-1}$ within $90 \mathrm{~min}$. Finally, the gradient was followed by an isocratic elution with $0.30 \mathrm{~mol} \cdot \mathrm{L}^{-1} \mathrm{NaCl}$ for $30 \mathrm{~min}$ and the column was washed with $1 \mathrm{~mol} \cdot \mathrm{L}^{-1}$ $\mathrm{NaCl}$ for $30 \mathrm{~min}$ at the same flow rate. The eluate was monitored at $280 \mathrm{~nm}$ and the fraction size was $6 \mathrm{~mL}$. The collected peaks were dialysed (MWCO $12 \mathrm{~kg} \cdot \mathrm{mol}^{-1}$, SigmaAldrich Chemie) against distilled water and lyophilised. Both buffers and samples were filtered through $0.45 \mu \mathrm{m}$ (Millipore Corporation, Bedford, USA). Their identity and purity were established by the reversedphase HPLC method of Jaubert and Martin [20] and the urea-PAGE method of Andrews [4], performed on a Hoefer miniVE Vertical Electrophoresis System (Amersham Pharmacia Biotech) in gel slabs $100 \times 100 \times 1 \mathrm{~mm}$. Proteins were fixed onto the gel by trichloroacetic acid $\left(150 \mathrm{~g} \cdot \mathrm{L}^{-1}\right)$ and stained by a Coomassie 
R-250 solution $\left(2.5 \mathrm{~g} \cdot \mathrm{L}^{-1}\right)$ in methanol, acetic acid and water (25:5:20). Gels were destained by a solution of glycerol, acetic acid, methanol and water (3:10:40:47).

\subsection{Reversed-phase HPLC (RP-HPLC)}

Reversed-phase HPLC analyses were performed by the method of Jaubert and Martin [20] on a Vydac C4 214 TP 5415 column (Separations Group, Hesperia, USA), at room temperature. The HPLC system consisted of a pump capable of mixing four solvents (Waters 600E, Waters), a photodiode array detector (Waters 996), a helium degasser, a Rheodyne 7125 injector (Rheodyne Inc., Cotati, CA, USA) and Millenium software (v.3.05.01, Waters). Solvent A was $1 \mathrm{~mL} \cdot \mathrm{L}^{-1}$ trifluroacetic acid (TFA, Serva Electrophoresis Gmbh, Heidelberg, Germany) in ultrapure water and solvent B was $0.96 \mathrm{~mL}$ TFA, $800 \mathrm{~mL}$ acetonitrile (Lichrosolv grade, Merck KGaA, Darmstadt, Germany) and $200 \mathrm{~mL}$ ultrapure water. Solvents were filtered through $0.45 \mu \mathrm{m}$ filters (Millipore Corporation). The flow rate was $1 \mathrm{~mL} \cdot \mathrm{min}^{-1}$. A linear gradient from $370 \mathrm{~mL} \cdot \mathrm{L}^{-1}$ to $530 \mathrm{~mL} \cdot \mathrm{L}^{-1}$ solvent $\mathrm{B}$ within $30 \mathrm{~min}$ was applied. Samples were prepared according to Pierre et al. [28] as follows: $30 \mathrm{mg}$ lyophilised casein were dissolved in $2 \mathrm{~mL}$ buffer, $\mathrm{pH} 7.0\left(0.1 \mathrm{~mol} \cdot \mathrm{L}^{-1}\right.$ tris, $8 \mathrm{~mol} \cdot \mathrm{L}^{-1}$ urea, $13 \mathrm{~g} \cdot \mathrm{L}^{-1}$ trisodium citrate and $10 \mathrm{mmol} \cdot \mathrm{L}^{-1}$ dithiothreitol adjusted to $\mathrm{pH} 7.0$ by $\mathrm{HCl}$ ), at $37^{\circ} \mathrm{C}$ for $60 \mathrm{~min}$, then $18 \mathrm{~mL}$ of solvent A containing $6 \mathrm{~mol} \cdot \mathrm{L}^{-1}$ urea were added and $\mathrm{pH}$ was adjusted to 2.2 by $50 \%$ TFA. After filtration through a $0.45 \mu \mathrm{m}$ filter (Millipore Corporation), $50 \mu \mathrm{L}$ were analysed. The protein content of the samples was adjusted after preliminary analyses. The heights of the major casein peaks at $214 \mathrm{~nm}$, were linearly correlated with the concentration of whole ovine casein in the sample, providing that the latter ranged from 20 to $100 \mu \mathrm{g}$ casein per injection. Four independent preparations of each sample were analysed.

\subsection{Isoelectric focusing (IEF) of caseins}

Whole and individual caseins obtained by $\mathrm{CE}$ chromatography were analysed by isoelectric focusing on ultrathin $(0.20 \mathrm{~mm})$ polyacrylamide gel $(\mathrm{C}=5 \%, \mathrm{~T}=3 \%$, $6 \mathrm{~mol} \cdot \mathrm{L}^{-1}$ urea) carried out in a LKB 2117 Multiphor II Electrophoresis Unit (Amersham Pharmacia Biotech). The gel layers were prepared with a mixture of ampholytes consisting of Pharmalyte ${ }^{\mathrm{TM}} \mathrm{pH}$ 2.5-5.0, Pharmalyte $^{\mathrm{TM}} \mathrm{pH}$ 4.5-5.4 and Ampholine ${ }^{\mathrm{TM}}$ pH 4.0-6.5 (Amersham Pharmacia Biotech) in a 1.6:1.4:1 ratio, according to Ferranti et al. [17]. Staining with Coomassie Brilliant Blue G-250 and destaining were according to the Commission Regulation [13].

\section{RESULTS AND DISCUSSION}

\subsection{Electrophoretic and chromato- graphic profiles of whole caseins}

The fractionation of ovine whole casein of the Frisarta flock on a SP-Sepharose cationexchange column is presented in Figure 1. According to urea-PAGE and RP-HPLC analyses, the first eluted group of substances consisted of $\beta$-mercaptoethanol and non-casein components. Peak 1 was $\beta$-casein. In peak 2 , nothing else but different forms of $\kappa$-casein were found and in peak $3, \kappa$-casein coexisted with bands that migrated in the region of $\gamma$-caseins. The content of peak $\times$ was not visualised by urea-PAGE, but in its RP-HPLC profile there was a hydrophobic peak with high retention time similar to that of $\beta$-casein. It can be attributed to $\gamma$-caseins that are expected to be co-eluted with $\beta$-caseins $[18,40]$. Peaks 4 and 5 consisted mainly of $\alpha_{\mathrm{s} 2^{-}}$-casein and also contained traces of $\alpha_{\mathrm{s} 1^{-}}$ casein. The last peak, 6 , was $\alpha_{\mathrm{s} 1}$-casein. In a cation-exchange Mono $\mathrm{S}$ column at 5.0, ovine $\alpha_{\mathrm{s} 1^{-}}$and $\alpha_{\mathrm{s} 2}$-caseins are co-eluted [9, 21], but by the present chromatographic analysis they were separated from each other. 


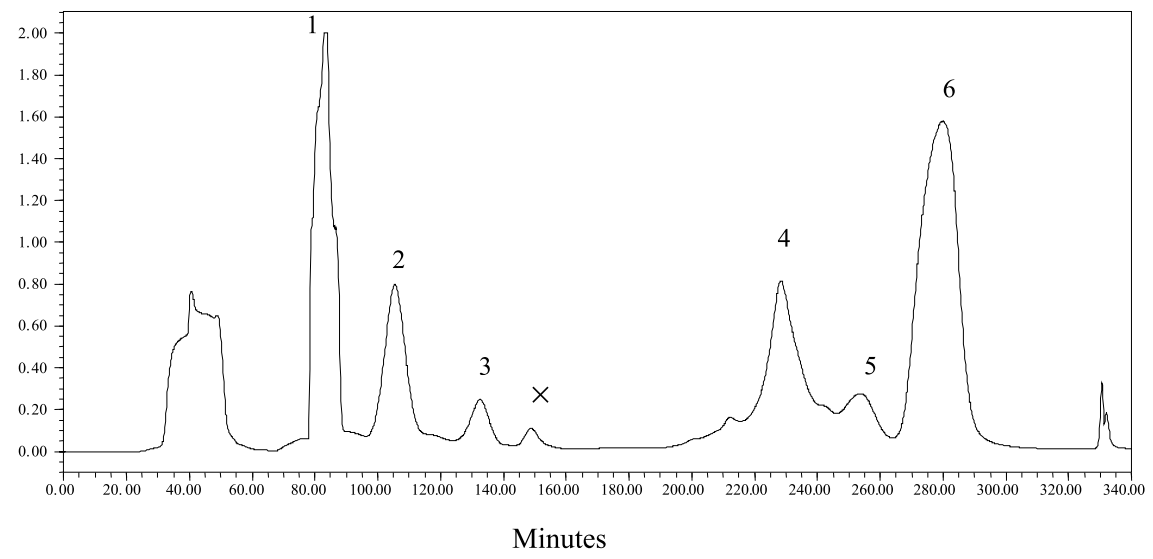

Figure 1. Cation-exchange chromatography $\left(\mathrm{A}_{280}\right)$ on a SP-Sepharose Hiload 26/10 column of whole ovine casein of the Frisarta breed (conditions and sample preparation are described in detail in Materials and methods).

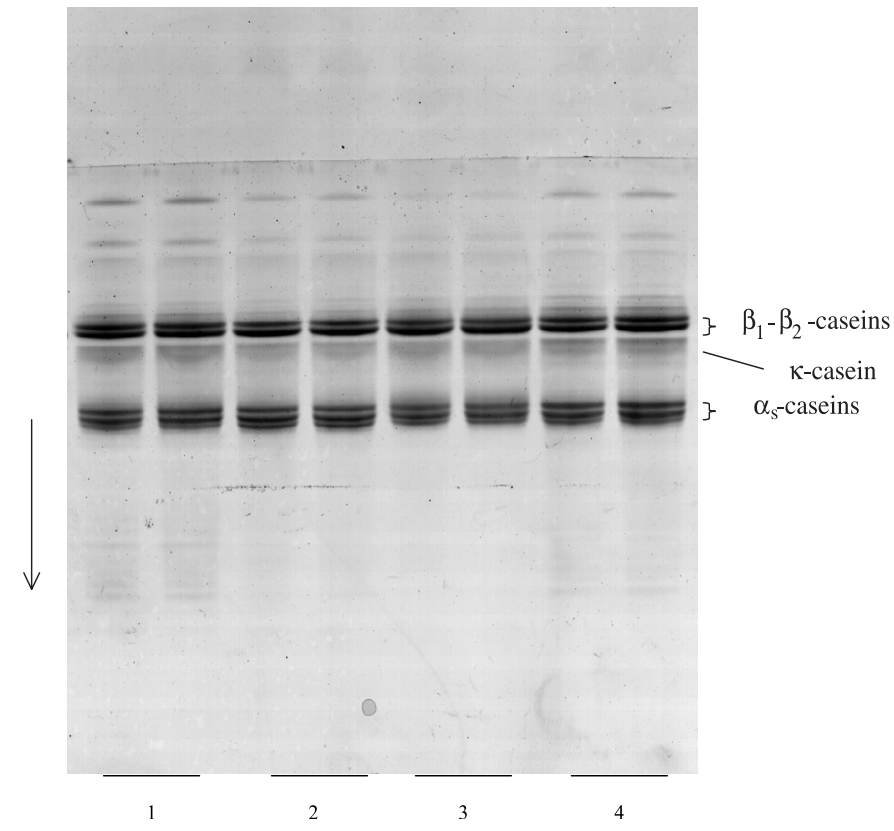

Figure 2. Urea-PAGE profiles of whole casein fractions from indigenous Greek ovine breeds. Lanes from 1 to 4, whole ovine casein fractions of the Frisarta, Chios, Karagouniko and Boutsiko breeds, respectively.

Urea-PAGE profiles of whole caseins are shown in Figure 2 and those of the chymosin and plasmin hydrolysates in Figure 3 a and b. In Figure 4, the reversed-phase HPLC profiles are presented. The identity of each peak was established after analysis of the individual caseins obtained by cationexchange chromatography (Fig. 1).

The elution pattern of $\alpha_{\mathrm{s} 1}$-casein was the most variable among the RP-HPLC 


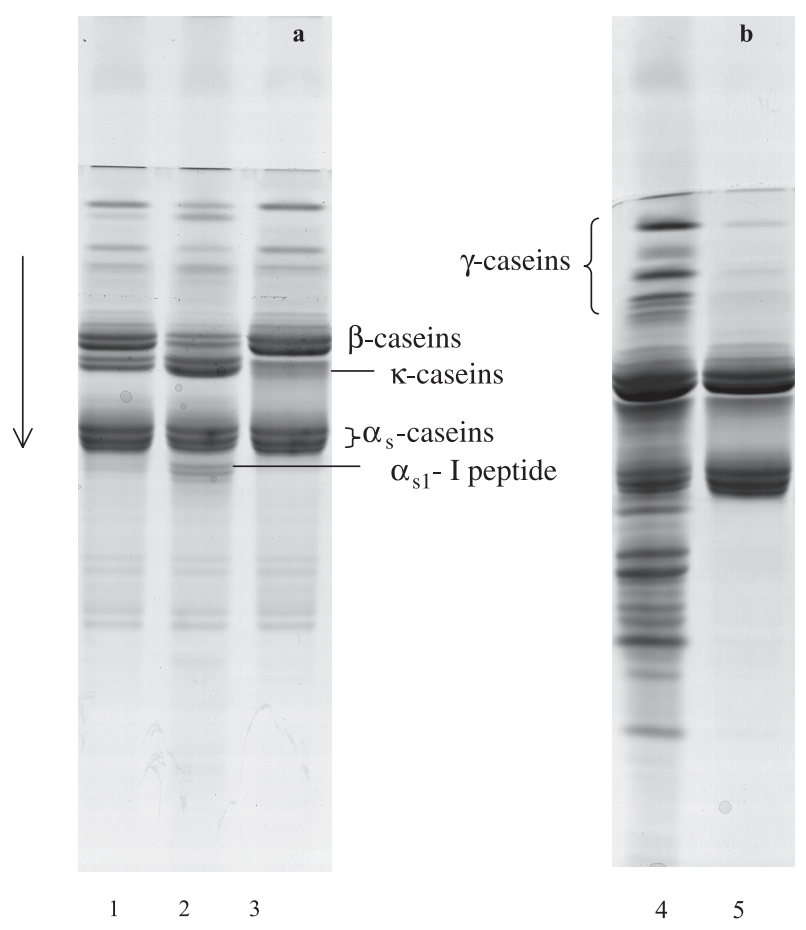

Figure 3. Urea-PAGE of whole ovine casein hydrolysates after treatment with chymosin (a) and plasmin (b). Lanes 1 and 2, whole ovine casein after 20 and $180 \mathrm{~min}$ of hydrolysis, respectively, with chymosin at $\mathrm{pH} 6.6$ (as described in Materials and methods); lane 3, unhydrolysed whole ovine casein; lane 4, whole ovine casein hydrolysate after treatment with plasmin (as described in Materials and methods); and lane 5, unhydrolysed whole ovine casein.

profiles of the different breeds (Fig. 4). In the Frisarta, Chios and Boutsiko profiles, there were two different $\alpha_{\mathrm{s} 1}$-casein peaks in different ratios, corresponding to the most frequent allelic forms within the breeds. It seemed that in the Karagouniko casein profile, there was one predominant variant of $\alpha_{\mathrm{s} 1}$-casein. There are six genetic variants of ovine $\alpha_{s 1}$-casein $[11,33]$, with co-existence of short non-allelic forms and differences in the phosphorylation level of each form. Mature $\alpha_{\mathrm{s} 1}$-casein is a mixture of at least seven molecular species [15-17]. The short forms of each variant are eluted earlier and the long forms follow in RPHPLC profiles, while the full-length protein has higher electrophoretic mobility
[14-16, 37]. Two of the six genetic variants, $\mathrm{C}$ and $\mathrm{B}$, are the most frequent in Italian and Spanish breeds, while $\mathrm{E}$ and $\mathrm{F}$ are very rare [3]. Apparently, all this heterogeneity was also depicted in the IEF profiles of $\alpha_{\mathrm{s} 1}$-casein (Fig. 5). In the IEF pattern of $\alpha_{\mathrm{s} 1}$-casein several bands appeared, two of them being predominant, corresponding to the most frequent allelic forms. Despite the fact that the $\alpha_{s 1}$-casein profile of the Karagouniko breed was found to be different from that of the other three breeds by the RP-HPLC method, the IEF profiles of the four breeds resembled each other (Fig. 5).

Regarding the $\alpha_{\mathrm{s} 2}$-peaks, there were differences between the RP-HPLC profiles. $\alpha_{\mathrm{s} 2}$-casein of the samples of the present 


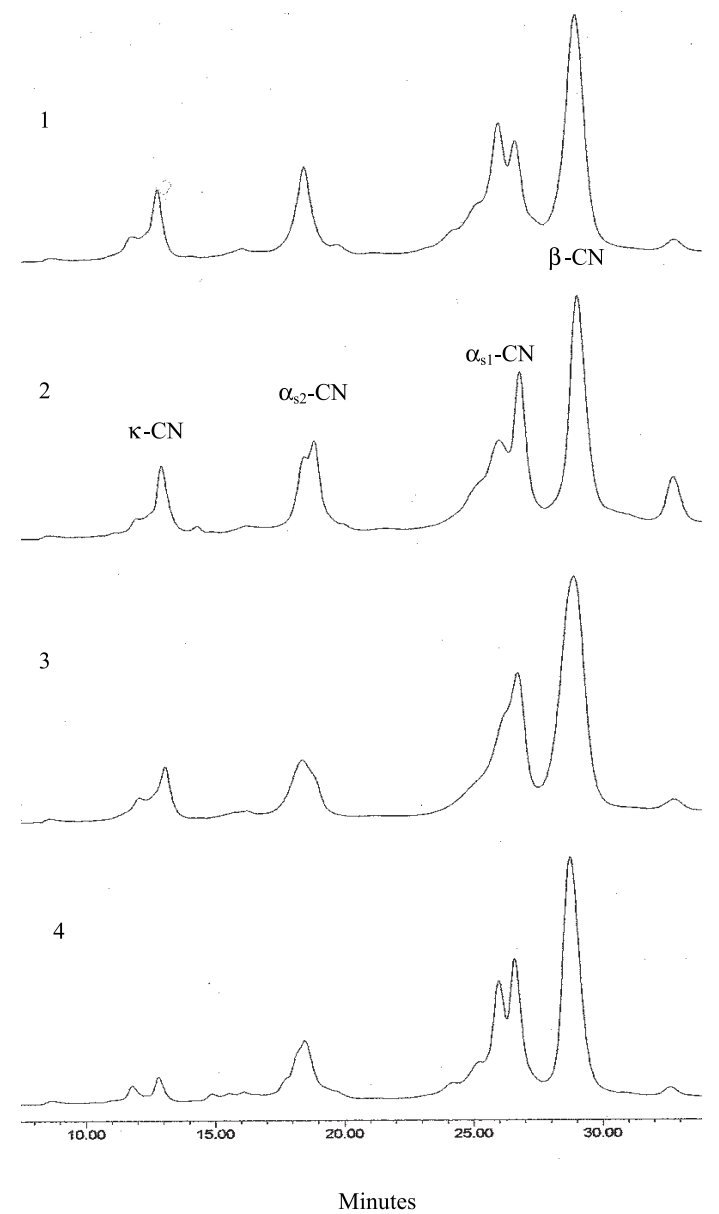

Figure 4. Reversed-phase HPLC profiles $\left(\mathrm{A}_{214}\right)$ of whole ovine caseins from indigenous Greek breeds (1, Frisarta; 2, Chios; 3, Karagouniko; and 4, Boutsiko).

study was resolved as two distinct but not well-resolved peaks or as a peak with rather broad shape on the reversed-phase column, as was the case of the Chios casein (Fig. 4). It is the most multisphorylated casein and similarly to its bovine counterpart, it displays genetic polymorphism expressed into two genetic variants and a non-allelic deleted form co-exists with the full-length protein [7, 17]. Eleven components and four main forms have been identified in the $\alpha_{\mathrm{s} 2}$-casein peak $[17,37]$. Moreover, IEF analysis of $\alpha_{\mathrm{s} 2}$-casein obtained by cationexchange chromatography revealed many bands (Fig. 5). Due to their heterogeneity, ovine $\alpha_{\mathrm{s} 1^{-}}$and $\alpha_{\mathrm{s} 2}$-caseins partly comigrated and they appeared as a group of three bands in the electrophoretic profiles (Fig. 2), as has also been reported by other researchers $[11,14,38]$.

Ovine $\beta_{1}$ - and $\beta_{2}$-caseins with 6 and 5 phosphates, respectively, migrated as two separated bands in the urea-PAGE profiles (Fig. 2) [36]. According to Chianese et al. [10] and Ferranti et al. [17] there are also multiphosphorylated forms with different mobilities containing 1-7 phosphates occurring simultaneously in individual ovine milks. Ovine $\beta$-casein was eluted as a single peak in all RP-HPLC profiles (Fig. 4). 


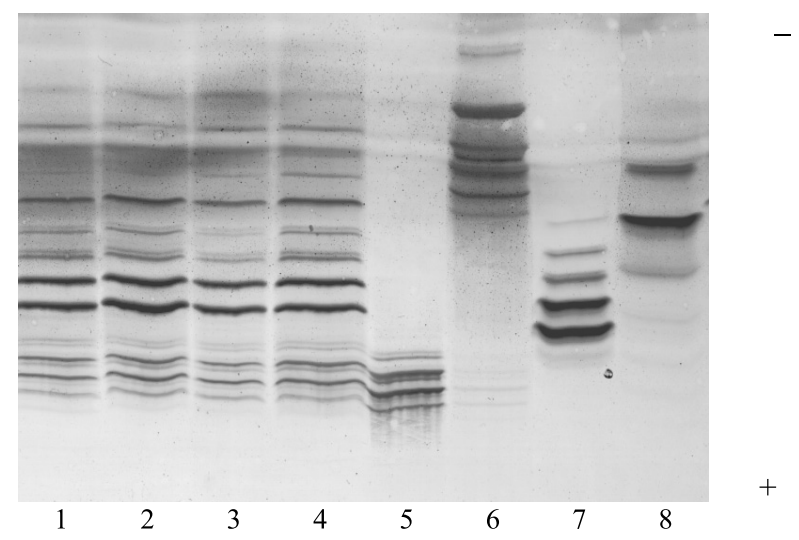

Figure 5. Isoelectric focusing (IEF) profiles on ultrathin gel, $\mathrm{pH}$ 2.5-6.5, of whole ovine caseins from indigenous Greek breeds. Lane 1, whole Boutsiko casein; lane 2, whole Karagouniko casein; lane 3, whole Chios casein; lane 4, whole Frisarta casein; lane 5, ovine $\alpha_{\mathrm{s} 1^{-}}$casein; lane 6 , ovine $\alpha_{\mathrm{s} 2^{-}}$ casein; lane 7 , ovine $\beta$-casein; and lane 8 , ovine $\kappa$-casein (conditions are described in detail in Materials and methods).

However, it seemed to be very heterogeneous in the IEF patterns (Fig. 5), where the $\beta_{1}$ - and $\beta_{2}$-casein bands were clearly demonstrated. The less intense bands could be attributed to the other multiphosphorylated forms [10, 17].

Ovine $\kappa$-caseins appeared as a diffused band in the electrophoresis profiles (Fig. 2). Apart from Alais and Jollès [2], who have reported $\mathrm{A}$ and $\mathrm{B} \kappa$-caseins in ovine milk, no genetic polymorphism has been reported for this casein. The high degree of $\kappa$-casein heterogeneity derived from the differences in phosphate and carbohydrate content is responsible for its shape in the RP-HPLC profiles of Figure 4 [17, 37]. It was eluted as two rather overlapped peaks. However, its IEF profile was more complex, presenting three main bands (Fig. 5). This complexity was in accordance with the reported IEF patterns of native and dephosphorylated ovine $\kappa$-casein $[8,17]$.

The position of $\kappa$-casein on the electrophoretic profiles migrating just ahead of $\beta$ casein (Fig. 2) as a diffused band was located after the analysis of the chymosin and plasmin hydrolysates by the same ureaPAGE method (Fig. 3 a, b). The disappear- ance of bovine $\kappa$-casein after hydrolysis with chymosin was not clearly evident in ovine casein hydrolysates because ovine $\kappa$-casein had the same mobility as proteolysis products of ovine $\beta$-casein (Fig. 3a). Hydrolysis of bovine whole casein by chymosin is accompanied by the appearance of the faster-moving $\alpha_{\mathrm{s} 1}-\mathrm{I}$ peptide derived from bovine $\alpha_{\mathrm{s} 1}$-casein $\left(\alpha_{\mathrm{s} 1}-\mathrm{CN}\right.$ f 24-191) in the urea-PAGE profiles [24]. The respective peptide in ovine casein hydrolysates became clearly evident after 180 min of hydrolysis as a couple of bands moving just ahead of the $\alpha_{\mathrm{s}}$-casein bands. The rate of hydrolysis of ovine $\beta$-casein and the appearance of the couple of $\beta$-I peptides $(\beta-C N$ f1-192) [26] in the area of the $\kappa$-casein, seemed faster than that of ovine $\alpha_{\mathrm{s} 1}$-casein. The appearance of $\beta$-I and $\alpha_{\mathrm{s} 1}$-I peptides as a couple of bands has been attributed to the phosphorylation differences in the respective sequences of the parent caseins $[15,36$, 38]. The presence of two bands of ovine $\alpha_{\mathrm{s} 1}$-I peptide could also be attributed to the different mobilities of the full-length and the deleted forms of ovine $\alpha_{\mathrm{s} 1}$-casein and of the different $\alpha_{\mathrm{s} 1}$-casein genotypes [16, 17, 33]. Plasmin treatment of whole casein gave rise to many new bands (Fig. 3b). 
Table I. Means ${ }^{1}$ and relative standard deviations (RSDs) ${ }^{2}$ for the relative percentages ${ }^{3}$ of $\alpha_{\mathrm{s} 1^{-}}, \alpha_{\mathrm{s} 2^{-}}$, $\beta$ - and $\kappa$-caseins in whole casein from indigenous Greek ovine breeds estimated by urea-PAGE and RP-HPLC.

\begin{tabular}{|c|c|c|c|c|c|c|c|}
\hline Breed & Method & $\kappa$-casein & $\alpha_{\mathrm{s}}$-casein ${ }^{4}$ & $\alpha_{\mathrm{s} 2}$-casein & $\alpha_{\mathrm{s} 1}$-casein & $\beta$-casein & $\alpha_{s}$-casein $4 / \beta$-casein \\
\hline \multirow[t]{2}{*}{ Frisarta } & Urea-PAGE & $10.4(12.6)$ & $51.7(3.4)$ & & & $37.9(3.4)$ & 1.36 \\
\hline & RP-HPLC & $10.2(3.3)$ & & $14.0(10.3)$ & $38.8(1.8)$ & $37.0(5.3)$ & 1.43 \\
\hline \multirow[t]{2}{*}{ Chios } & Urea-PAGE & $9.8(21.0)$ & $53.2(2.4)$ & & & $37.0(4.4)$ & 1.44 \\
\hline & RP-HPLC & $10.2(5.6)$ & & $16.4(2.9)$ & $36.3(3.5)$ & $37.1(4.4)$ & 1.42 \\
\hline \multirow[t]{2}{*}{ Karagounik } & roUrea-PAGE & $10.3(26.5)$ & $48.3(4.7)$ & & & $41.4(2.5)$ & 1.17 \\
\hline & RP-HPLC & $10.8(8.0)$ & & $13.0(3.9)$ & $33.9(2.2)$ & $42.3(3.4)$ & 1.11 \\
\hline \multirow[t]{2}{*}{ Boutsiko } & Urea-PAGE & $10.4(9.9)$ & $50.2(3.0)$ & & & $39.4(4.4)$ & 1.27 \\
\hline & RP-HPLC & $9.1(1.5)$ & & $12.0(8.3)$ & 39.9 (5.6) & 39.0 (3.6) & 1.33 \\
\hline
\end{tabular}

${ }^{1}$ Means of quantification of four independent sample preparations $(n=4) ;{ }^{2}$ standard deviation expressed as percentage of the mean; ${ }^{3}$ expressed as percentage of total $\alpha_{\mathrm{s} 1}, \alpha_{\mathrm{s} 2^{-}}, \beta$ - and $\kappa$-caseins; ${ }^{4} \alpha_{\mathrm{s} 1^{-}}$ casein $+\alpha_{\mathrm{s} 2}$-casein.

Apart from $\gamma$-caseins [5] many new distinct bands with mobility greater than that of $\alpha_{\text {s- }}$ caseins appeared, that could result from the hydrolysis of $\alpha_{\mathrm{s} 1}$-casein by plasmin, as is reported for its bovine counterpart $[22,25]$. The ovine $\kappa$-casein band was clearly demonstrated in the plasmin hydrolysates, since it is quite resistant to plasmin action, according to the data reviewed by Bastian and Brown [5].

\subsection{Quantification of casein fractions}

The quantification results of the ureaPAGE profiles expressed as relative percentages of $\alpha_{\mathrm{s}}-, \beta$ - and $\kappa$-caseins are presented in Table I. Regarding the results of ureaPAGE analyses, $\alpha_{\mathrm{s} 1^{-}}$and $\alpha_{\mathrm{s} 2}$-caseins were estimated as the group of $\alpha_{\mathrm{s}}$-caseins because they co-migrated, as explained in the previous section. A part of the $\kappa$-casein components was not expected to be quantified because they are overlapping with $\beta$-casein bands $[8,14]$. The overestimation of $\beta$-casein bands was negligible, since its content was much higher in comparison with that of $\kappa$-casein. The quantification of $\gamma$-caseins was uncertain and since they are greatly affected by the treatment of milk samples, they were excluded from the quantification results of Table I. In Table I, the results from the RP-HPLC analyses are also presented. The relative quantities of different caseins were estimated by calculating the individual peak areas as a percentage of the sum of all peaks.

The relative percentages of the individual ovine caseins estimated by PAGE and RP-HPLC were similar (Tab. I). However, there were differences between the breeds estimated by both methods, especially concerning the $\alpha_{\mathrm{s}}$ - and $\beta$-caseins content. The relative standard deviations (RSDs) of $\kappa$ casein means estimated by urea-PAGE were very high, because of its appearance as a diffused band, its partial co-migration with $\beta$-casein and its low content.

The results of Table I were in some cases different from those reported for ovine casein fractions, especially regarding, $\alpha_{\mathrm{s}}$ - and $\beta$-caseins. The percentage of $\kappa$-casein, ranging from $9.1 \%$ to $10.8 \%$, was similar to that reported for the milk of Sardinian ewes by Law et al. [21] and Papoff et al. [27] who used cation-exchange chromatography. Similarly, Pirisi et al. [33] have estimated by RP-HPLC the $\kappa$-casein relative percentage as $9.8 \%$ in ovine milks 
from Sarda sheep of CC and CD genotypes. However, it was much lower than that reported for the casein of Lacha Spanish sheep, by Calavia and Burgos [8]. They have estimated the $\kappa-\mathrm{CN}$ percentage to total ovine casein to be $17 \%$, by densitometric analysis of the PAGE electrophoregrams of the SH containing casein.

Both $\alpha_{\mathrm{s} 1^{-}}$and $\alpha_{\mathrm{s} 2}$-casein percentages were quite variable among the different breeds. The $\alpha_{\mathrm{s} 2}$-casein percentage of the ovine samples, ranging from $12.0 \%$ to $16.4 \%$, was higher than that reported by Calavia and Burgos [8]. Pirisi et al. [33] have reported that the relative $\alpha_{\mathrm{s} 2}$-casein percentage ranges from $11.9 \%$ to $13.9 \%$ depending on the $\alpha_{\mathrm{s} 1}$-casein genotype of ovine milk. The relative quantity of $\alpha_{\mathrm{s} 1^{-}}$ casein was also variable (from $33.9 \%$ to $38.8 \%$ ) among the different breeds and the lowest value was observed in the Karagouniko breed $(33.9 \%)$. Total $\alpha_{\mathrm{s}}$-casein percentage ranged from $46.9 \%$ to $52.8 \%$ according to RP-HPLC and from $48.3 \%$ to $53.2 \%$ according to the PAGE results. These values were in general higher than those reported for ovine $\alpha_{s}$-caseins by other researchers. Addeo et al. [1] and Calavia and Burgos [8] have estimated the ovine $\alpha_{s}$-caseins relative percentage as $45 \%$ and $43 \%$, respectively. Law et al. [21] and Papoff et al. [27] report very low values of this percentage, $34.2 \%$ and $26.8 \%$, respectively. However, Pirisi et al. [33] report relative percentages of $\alpha_{\mathrm{s}}$-caseins from $45.3 \%$ to $50.2 \%$, depending on the $\alpha_{\mathrm{s} 1}$-casein genotype, which are close to the values of the present study.

$\beta$-Casein of the studied milks ranged from $37.0 \%$ to $42.3 \%$ of total casein according to RP-HPLC and from $37.0 \%$ to $41.4 \%$ according to the PAGE results. The highest value was estimated by both methods in Karagouniko casein. Calavia and Burgos [8] found that the $\beta$-casein percentage in the Spanish Lacha milk is about $38 \%$ in whole casein. Law et al. [21] and Papoff et al. [27] found that in the whole casein fraction of Sardinian ewes, $\beta$-casein accounts for about $50 \%$, but Pirisi et al. [33] report percentages of $\beta$-casein from $40 \%$ to $43 \%$.

There is a link between $\alpha_{\mathrm{s} 1}$-casein genetic variants and milk composition, which affects cheese yield [12, 31, 32]. According to the conclusions of Amigo et al. [3], the $\alpha_{s 1}$-casein D variant, even in association with others, results in lower casein content and poorer technological properties of ovine milk. From the results of Pirisi et al. [33], it is obvious that a lower $\alpha_{s}$-casein $/ \beta$-casein ratio in ovine milk, similar to that estimated in Karagouniko casein, is related to lower total protein and casein content of milk, greater micellar size, and longer clotting time and curd firming rate. From the results of the present study, Karagouniko milk would be expected to have inferior technological properties, compared with the milk of the other three breeds, although its IEF profile was not different regarding the $\alpha_{\mathrm{s} 1}$-casein bands. Therefore, a further study has to be undertaken to relate the casein characteristics and technological properties of the milks of the present study.

\section{CONCLUSIONS}

Regarding the differences between the indigenous Greek ovine breeds, it seemed that in addition to the heterogeneity that was depicted in the peak shape of caseins, there was also quantitative variability, especially concerning the main casein groups $\left(\alpha_{\mathrm{s}}-\right.$ and $\beta$-caseins). Casein from the Karagouniko breed had the greatest $\beta$-casein content and the lowest $\alpha_{s}$ - to $\beta$-casein ratio, while the relative percentages of the individual caseins in the Frisarta and Chios breeds were very similar. The effect of this variability on the technological properties and especially on the cheesemaking properties of ovine milk has to be studied.

The RP-HPLC method of Jaubert and Martin [20] was appropriate for the analyses of ovine casein as it is for caprine 
caseins. The heterogeneity of the individual caseins was depicted more clearly than by urea-PAGE. Furthermore, $\alpha_{s}$-caseins were resolved in $\alpha_{\mathrm{s} 1^{-}}$and $\alpha_{\mathrm{s} 2}$-peaks. Although the estimated relative percentages by both methods were similar, the RSDs of RPHPLC means were much better. Fractionation by cation-exchange chromatography resulted in a very satisfactory separation of whole ovine casein components.

\section{REFERENCES}

[1] Addeo F., Mauriello R., Moio L., Laezza P., Chianese L., Di Luccia A., Ovine casein variant identification using electrophoretic, immunochemical and chromatographic techniques, Milchwissenschaft 47 (1992) 283-287.

[2] Alais C., Jollès P., Isolation, purification and analysis of two $\kappa$-casein-like fractions from sheep casein, J. Dairy Sci. 50 (1967) 15551561 .

[3] Amigo L., Recio I., Ramos M., Genetic polymorphism of ovine milk proteins: its influence on technological properties of milk - a review, Int. Dairy J. 10 (2000) 135149.

[4] Andrews A.T., Proteinases in normal bovine milk and their action on caseins, J. Dairy Res. 50 (1983) 45-55.

[5] Bastian E.D., Brown R.J., Plasmin in milk and dairy products: an update, Int. Dairy J. 6 (1996) 435-457.

[6] Blakesley R.W., Boezzi J.A., A new staining technique for protein in polyacrylamide gels using Coomassie Brilliant Blue G-250, Anal. Biochem. 82 (1977) 580-582.

[7] Boisnard M., Hué D., Bouniol C., Mercier J.-C., Gaye P., Multiple mRNA species code for two non-allelic forms of ovine $\alpha_{\mathrm{s}_{2}}$ casein, Eur. J. Biochem. 201 (1991) 633641.

[8] Calavia M.C., Burgos J., Ovine א-casein in milk from Lacha Spanish sheep: heterogeneity and total content, Int. Dairy J. 8 (1998) 779-786.

[9] Cattaneo T.M.P., Nigro F., Toppino P.M., Denti V., Characterization of ewe's milk by capillary zone electrophoresis, J. Chromatogr. 721 (1996) 345-349.

[10] Chianese L., Garro G., Ferranti P., Malorni A., Addeo F., Rabasco A., Molina Pons P., Discrete phosphorylation generates the electrophoretic heterogeneity of ovine $\beta$-casein, J. Dairy Res. 62 (1995) 89-100.
[11] Chianese L., Garro G., Mauriello R., Laezza P., Ferranti P., Addeo F., Occurrence of five $\alpha_{\mathrm{s} 1}$-casein variants in ovine milk, J. Dairy Res. 63 (1996) 49-59.

[12] Chianese L., Mauriello R., Ferranti P., Tripaldi C., Taibi L., Dell'Aquilla S., Relationship between $\alpha_{s 1}$-casein variants and clotting capability of ovine milk, in: "Milk and milk protein polymorphism”, Special Issue 9702 , Int. Dairy Fed., Brussels, Belgium (1997) pp. 316-323.

[13] Commission Regulation, Reference method for the detection of cow's milk and caseinate in cheeses from ewes' milk, goats' milk and buffalos' milk or mixtures of ewes', goats' and buffalos' milk, EEC No 1081/96, 14 June 1996, J. Eur. Commun. 142 (1996) 15-25.

[14] Dall'Olio S., Davoli R., Russo V., Affinity chromatography of ovine casein, J. Dairy Sci. 73 (1990) 1707-1711.

[15] Ferranti P., Malorni A., Nitti G., Laezza P., Pizzano R., Chianese L., Addeo F., Primary structures of ovine $\alpha_{\mathrm{s} 1}$-caseins: localization of phosphorylation sites and characterization of genetic variants A, C and D*, J. Dairy Res. 62 (1995) 281-296.

[16] Ferranti P., Chianese L., Malorni A., Migliaccio F., Stingo V., Addeo F., Copresence of deleted protein species generates structural heterogeneity of ovine $\alpha_{\mathrm{s} 1}$-casein, J. Agric. Food Chem. 46 (1998) 411-416.

[17] Ferranti P., Pizzano R., Garro G., Caira S., Chianese L., Addeo F., Mass spectrometrybased procedure for the identification of ovine casein heterogeneity, J. Dairy Res. 68 (2001) 35-51.

[18] Groen A.F., van der Vegt R., van Boeckel M.A.J.S., de Rouw O.L.A.M., Vos H., Case study on the individual animal variation in milk protein composition as estimated by high-performance liquid chromatography, Neth. Milk Dairy J. 48 (1994) 201-212.

[19] Hollar C.M., Law A.J.R., Dalgleish D.G., Brown R.J., Separation of major casein fractions using cation exchange fast protein liquid chromatography, J. Dairy Sci. 74 (1991) 2403-2409.

[20] Jaubert A., Martin P., Reverse-phase HPLC analysis of goat caseins. Identification of $\alpha_{\mathrm{s}}$ and $\alpha_{\mathrm{s} 2}$ genetic variants, Lait 72 (1992) 235247.

[21] Law A.J.R., Papoff C.M., Dalgleish D.G., Campus R.L., Quantitative fractionation of ovine casein by cation exchange FPLC, Milchwissenschaft 47 (1992) 279-282.

[22] Le Bars D., Gripon J.C., Hydrolysis of $\alpha_{\mathrm{s} 1}$ casein by bovine plasmin, Lait 73 (1993) 337-344. 
[23] López-Gálvez G., Ramos M., Martín-Álvarez P.J., Juárez M., Influence of milk proteins polymorphism on cheese producing ability in the milk of Manchega breed cows, in: "Cheese yield and factors affecting its control", Special Issue 9402, Int. Dairy Fed., Brussels, Belgium (1994) pp. 167-173.

[24] McSweeney P.L.H., Olson N.F., Fox P.F., Healy A., Højrup P., Proteolytic specificity of chymosin on bovine $\alpha_{\mathrm{s} 1}$-casein, J. Dairy Res. 60 (1993) 401-412.

[25] McSweeney P.L.H., Olson N.F., Fox P.F., Healy A., Højrup P., Proteolytic specificity of plasmin on bovine $\alpha_{\mathrm{si}}$-casein, Food Biotechnol. 7 (1993) 143-158.

[26] Mulvihill D.M., Fox P.F., Proteolytic specificity of chymosins and pepsin on $\beta$-caseins, Milchwissenschaft 34 (1979) 680-683.

[27] Papoff C.M., Law A.J.R., Dalgleish D.G., Campus R.L., Determination of the composition of ovine casein by anion-exchange FPLC, Sci. Tec. Latt. Casearia 44 (1993) 273-291.

[28] Pierre A., Michel F., Le Graët Y., Variation in size of goat milk casein micelles related to casein genotype, Lait 75 (1995) 489-502.

[29] Pierre A., Michel F., Le Graët Y., Zahoute L., Casein micelle size in relation with casein composition and $\alpha_{\mathrm{s} 1}, \alpha_{\mathrm{s} 2}, \beta$ and $\kappa$ casein in goat milk, Lait 78 (1998) 591-605.

[30] Pirisi A., Collin O., Laurent F., Scher J., Parmentier M., Comparison of milk composition, cheesemaking properties and textural characteristics of the cheese from two groups of goats with a high or low rate of $\alpha_{\text {s1 }}$-casein synthesis, Int. Dairy J. 4 (1994) 329-345.

[31] Pirisi A., Piredda G., Di Salvo R., Papoff C.M., Pintus S., Influence of ovine $\alpha_{s 1-}$ casein genotype on milk composition and cheese yielding capacity, in: "Production and utilization of ewe and goat milk", Special Issue 9603, Int. Dairy Fed., Brussels, Belgium (1996) pp. 179-183.
[32] Pirisi A., Piredda G., Fraghi A., Papoff C.M., Chianese L., Influence of sheep AA, $\mathrm{CC}$ and DD $\alpha_{\mathrm{s} 1}$-casein variants on milk composition and cheese yield, in: "Milk protein polymorphism", Special Issue 9702, Int. Dairy Fed., Brussels, Belgium (1997) pp. 254-258.

[33] Pirisi A., Piredda G., Papoff C.M., Di Salvo R., Pintus S., Garro G., Ferranti P., Chianese L., Effects of sheep $\alpha_{\mathrm{s} 1}$-casein CC, CD and DD genotypes on milk composition and cheesemaking properties, J. Dairy Res. 66 (1999) 409-419.

[34] Provot C., Persuy M.A., Mercier J.C., Complete nucleotide sequence of ovine $\beta$-casein cDNA: inter-species comparison, Biochimie 71 (1989) 827-832.

[35] Remeuf F., Influence du polymorphisme génétique de la caséine $\alpha_{\mathrm{s} 1}$ caprine sur les caractéristiques physico-chimiques et technologiques du lait, Lait 73 (1993) 549-557.

[36] Richardson B.C., Mercier J.C., The primary structures of ovine $\beta$-casein, Eur. J. Biochem. 99 (1979) 285-297.

[37] Trujillo A.-J., Casals I., Guamis B., Analysis of major ovine milk proteins by reversed phase high-performance liquid chromatography and flow injection analysis with electrospray ionization mass spectrometry, J. Chromatogr. 870 (2000) 371-380.

[38] Trujillo A.J., Guamis B., Laencina J., López M.B., Proteolytic activities of some milk clotting enzymes on ovine casein, Food Chem. 71 (2000) 449-457.

[39] Vassal L., Delacroix-Buchet A., Bouillon J., Influence des variants AA, EE et FF de la caséine $\alpha_{\mathrm{s} 1}$ caprine sur le rendement fromager et les caractéristiques sensorielles de fromages traditionnels: premières observations, Lait 74 (1994) 89-103.

[40] Visser S., Slangen K.J., Rollema H.S., High performance liquid chromatography of bovine caseins with the application of various stationary phases, Milchwissenschaft 41 (1986) 559-562. 